\title{
Shu-Sheng Liaw (Taiwan) \\ Investigating Learner Attitudes toward Mobile Learning Environments: Based on Gender Perspectives
}

\begin{abstract}
Summary: Mobile technology, accessing Internet resources anytime and anywhere, empowers the shift from traditionally pure instructor-centered classroom teaching to fully learner-centered educational settings. On the other hand, the issue of the relationship between gender perspectives and mobile learning environments has been a controversial topic in educational technology. Therefore, the main research objective of this study is to explore gender perspectives of attitudes toward mobile learning environments. Subjects of the study were selected university students who had already used an APP-based m-learning system for a month. A total of two hundred thirty-three valid questionnaires were collected, spilt evenly between female and male students. Based on gender perspectives, our statistical analyses lead to various significant conclusions.
\end{abstract}

Keywords: mobile learning, gender studies, interactive learning, postsecondary education

Резюме (Шу-Шенг Лиав: Исследование отношения к учению в контексте мобильной среды обучения и на основании гендерной перспективы): Мобильная технология, доступ к интернетресурсам в любое время и в любом месте обеспечивает смещение традиционных, нацеленных только на учителя методов обучения в направлении учебных заведений, полностью концентрирующихся на обучающихся. С другой стороны, вопрос об отношениях между гендерной перспективой и мобильной средой обучения представляет собой тему для дискуссий в образовательной технологии. В связи с этим, главной целью данного исследования является изучение отношения к мобильной среде с позиции гендерной перспективы. Субъектами исследования были студенты, использовавшие систему мобильного обучения на основе приложения АРР уже в течение месяца. Всего было собрано 233 анкеты, одновременно разделенные между студентами женского и мужского пола. На основании гендерной перспективы наши статистические анализы привели кразличным по важности заключениям.

Ключевые слова: мобильное обучение, гендерные исследования, интерактивное обучение, высшее образование

Zusammenfassung (Shu-Sheng Liaw: Untersuchung von Lernhaltungen im Kontext mobiler Lernumgebungen und auf der Grundlage der Geschlechterperspektive): Die Mobiltechnologie, der jederzeit und überall verfügbare Zugriff auf Internet-Ressourcen ermöglicht die Verschiebung traditioneller, rein lehrer-zentrierter Unterrichtsmethoden in Richtung vollständig lernerzentrierter Bildungseinrichtungen. Auf der anderen Seite ist die Frage nach der Beziehung zwischen Geschlechterperspektiven und mobilen Lernumgebungen ein umstrittenes Thema in der Bildungstechnologie. Daher ist das Hauptforschungsziel dieser Studie die Erkundung der Haltungen gegenüber mobilen Lernumgebungen aus der Geschlechterperspektive. Subjekte der Studie wurden Studenten, die bereits für einen Monat ein APP-basiertes M-Learning-System genutzt hatten. Insgesamt wurden 233 gültige Fragebögen gesammelt, gleichmäßig verteilt zwischen weiblichen und männlichen Studenten. Auf der Grundlage der Geschlechterperspektive führen unsere statistischen Analysen zu verschiedenen signifikanten Schlussfolgerungen.

Schlüsselwörter: mobiles Lernen, Gender-Studien, interaktives Lernen, Hochschulbildung 


\section{Introduction}

Advanced applications in information and Internet technologies now allow learners and teachers to exploit the potential learning effectiveness of mobile-based learning. Essentially, m-learning (mobile learning) environments are blooming all over the world. They range from the use of tablet computers, or notebook computers in classrooms, through smart mobile phones to support learning between schools and learners. This research tries to understand the use of an APP-based m-learning system as learning tools in terms of learners' self-efficacy, self-regulation, anxiety, satisfaction, usefulness, and behavioral acceptance. Based on the research approach, the study develops a research model to investigate learners' attitudes toward mobile learning acceptance.

M-learning systems, accessing Internet resources anytime and anywhere, empowers the shift from traditionally pure instructor-centered classroom teaching to fully learner-centered educational settings. Essentially, m-learning could be defined as "learning across multiple contexts, through social and content interactions, using personal electronic devices" (Crompton, 2013, p.4). Although we do not expect m-learning to fully replace formal classroom learning or other formal learning approaches; however, m-learning can complement and add value to the existing learning styles or learning models.

From advantages of m-learning, the main research purpose is to explore attitudes toward m-learning environments based on gender perspective. Specifically; this research surveys the gender difference about female and male university students' attitudes toward using APP-based m-learning environments. Indeed, investigating gender perspectives of behavioral acceptance toward APP-based mlearning systems is now a critical issue in the field of educational technology.

\section{Research hypotheses}

The m-learning measurement should incorporate different aspects of learner perceptions to facilitate the creation of appropriating m-learning environments for teaching and learning. Additionally, understanding gender difference toward m-learning is the major research objective of this study. Previous studies (Albert \& Johnson, 2011; Chu, 2010; Liaw, 2002; Liaw, 2007; Ong \& Lai, 2006) are not conclusive with respect to the level of positive attitudes toward educational technology. Therefore, based on our research model as shown in Figure 1, we propose our research hypotheses as follows.

H1: Perceived self-efficacy has positive predictive value for perceived satisfaction toward m-learning.

H2: Perceived self-efficacy has positive predictive value for perceived usefulness toward m-learning.

H3: Perceived self-regulation has positive predictive value for perceived satisfaction toward m-learning.

H4: Perceived self-regulation has positive predictive value for perceived usefulness toward m-learning.

H5: Interactive learning environments have positive predictive value for perceived satisfaction toward m-learning.

H6: Interactive learning environments have positive predictive value for perceived usefulness toward m-learning.

H7: Perceived ease of use has positive predictive value for perceived satisfaction toward m-learning. H8: Perceived ease of use has positive predictive value for perceived usefulness toward m-learning. H9: Perceived anxiety has negative predictive value for perceived satisfaction toward m-learning. H10: Perceived anxiety has negative predictive value for perceived usefulness toward m-learning. 
H11: Perceived satisfaction has positive predictive value for behavioral acceptance toward m-learning.

H12: Perceived usefulness has positive predictive value for behavioral acceptance toward m-learning.

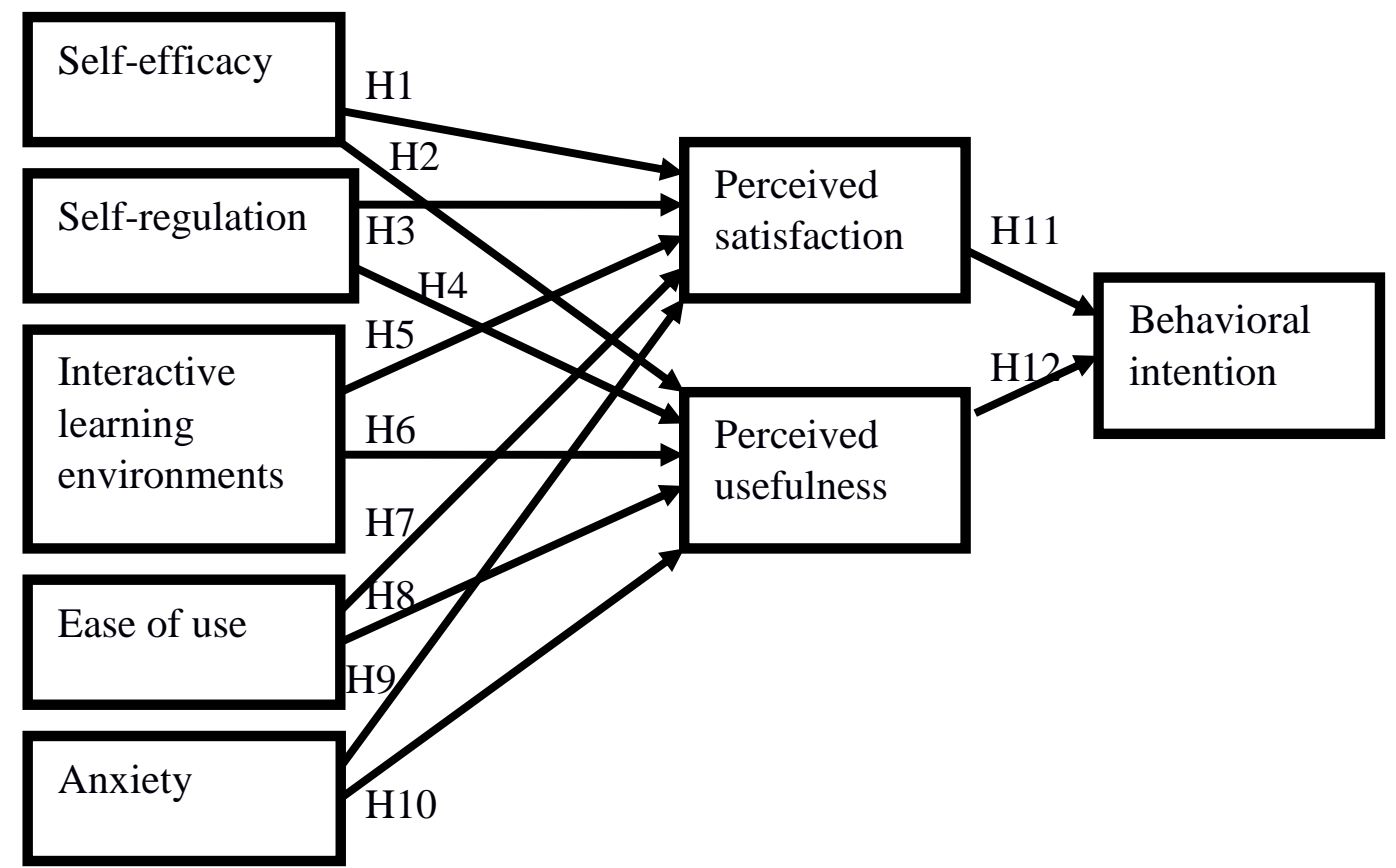

Fig-

ure 1: The model of research hypotheses

\section{Methodology}

\section{Participants}

To understand learner attitudes toward the APP-based m-learning system, the questionnaire collected demographic information and posed questions related to experience using computers and Internet; attitudes toward the APP-based m-learning system also were included in this questionnaire. The paper-based questionnaires were distributed with a cover letter. A total of 233 valid responses were collected, 135 female learners and 98 male participants.

\section{Measurement}

The questionnaire covers eight factors. The five factors of perceived self-efficacy, perceived anxiety, perceived usefulness, interactive learning environments, and behavioral acceptance were modified from Liaw et al. (2010) ( $\alpha=0.96)$. Questionnaire items for self-regulation and perceived satisfaction were revised from Liaw and Huang (2013) $(\alpha=0.95)$. Items for perceived ease of use were revised from Sun et al., (2008) ( $\alpha=0.90)$. Based on these studies, questionnaire items were designed to focus on investigating learner attitudes toward learning systems. The eight-factor questionnaire covered 30 items, each item using a 7-point Likert scale ( 1 = "strongly disagree" to 7 = "strongly agree"). 


\section{Results}

In this research, PLS technique was applied to detect relationships among eight factors (perceived self-efficacy, perceived self-regulation, interactive learning environments, perceived ease of use, perceived anxiety, perceived satisfaction, perceived usefulness, and behavioral acceptance). After PLS analyses, Table 1 showed the results of 12 hypotheses (including female and male learners). From the results for female learners, four hypotheses were not supported that included H7, H8, H9, and H10. For the male learners, one hypothesis (H4) was not supported.

Table 1: Research results of hypotheses

\begin{tabular}{|c|c|c|c|c|c|c|c|}
\hline \multirow{2}{*}{$\begin{array}{l}\text { Hypothe- } \\
\text { sis }\end{array}$} & \multirow{2}{*}{$\begin{array}{l}\text { Female stu- } \\
\text { dents } \\
\text { Prediction }\end{array}$} & \multicolumn{6}{|c|}{ Male students } \\
\hline & & $\beta$ & $\mathrm{p}$ & true & $\beta$ & $\mathrm{P}$ & True \\
\hline H1 & $\begin{array}{l}\text { Self-effi- } \\
\text { cacy? } \text { satisfac- } \\
\text { tion }\end{array}$ & .169 & $<.01$ & Yes & .195 & $<.01$ & Yes \\
\hline $\mathrm{H} 2$ & $\begin{array}{l}\text { Self-effi- } \\
\text { cacy? useful- } \\
\text { ness }\end{array}$ & .316 & $<.01$ & Yes & .433 & $<.01$ & Yes \\
\hline H3 & $\begin{array}{l}\text { Self-regula- } \\
\text { tion?satisfac- } \\
\text { tion }\end{array}$ & .264 & $<.01$ & Yes & .067 & $<.05$ & Yes \\
\hline $\mathrm{H} 4$ & $\begin{array}{l}\text { Self-regula- } \\
\text { tion? } \begin{array}{l}\text { ?useful- } \\
\text { ness }\end{array}\end{array}$ & .120 & $<.01$ & Yes & & & No \\
\hline H5 & $\begin{array}{l}\text { Interactive lear- } \\
\text { ning? } \text { ?atisfac- } \\
\text { tion }\end{array}$ & .404 & $<.01$ & Yes & .606 & $<.01$ & Yes \\
\hline H6 & $\begin{array}{l}\text { Interactive lear- } \\
\text { ning? } \text { ? } \\
\text { ness }\end{array}$ & .563 & $<.01$ & Yes & .266 & $<.01$ & Yes \\
\hline H7 & $\begin{array}{l}\text { Ease of use? sa- } \\
\text { tisfaction }\end{array}$ & & & No & .075 & $<.01$ & Yes \\
\hline H8 & $\begin{array}{l}\text { Ease of } \\
\text { use目usefulness }\end{array}$ & & & No & .175 & $<.01$ & Yes \\
\hline H9 & $\begin{array}{l}\text { Anxiety?satis- } \\
\text { faction }\end{array}$ & .109 & $<.01$ & No & -.088 & $<.01$ & Yes \\
\hline H10 & $\begin{array}{l}\text { Anxiety? useful- } \\
\text { ness }\end{array}$ & .105 & $<.01$ & No & -.034 & $<.05$ & Yes \\
\hline H11 & Satisfac- & .306 & $<.01$ & Yes & .424 & $<.01$ & Yes \\
\hline
\end{tabular}




\begin{tabular}{|l|l|l|l|l|l|l|l|}
\hline & $\begin{array}{l}\text { tion?accep- } \\
\text { tance }\end{array}$ & & & & & & \\
\hline H12 & $\begin{array}{l}\text { Usefulness!ac- } \\
\text { ceptance }\end{array}$ & .598 & $<.01$ & Yes & .505 & $<.01$ & Yes \\
\hline
\end{tabular}

\section{Discussions}

Based on gender perspective, it is an issue when understanding learners' attitudes toward m-learning environments; especially APP-based learning systems. In our statistical results, perceived selfefficacy is a more critical predictor on perceived satisfaction and perceived usefulness for female students than male students. Regarding perceived self-regulation of perceived satisfaction and perceived usefulness, like perceived self-efficacy, it has more contribution for female learners than male learners. Indeed, perceived self-regulation is not a predictor on perceived usefulness for male learners. Interactive learning environment is a crucial predictive factor for both female and male students; no matter perceived satisfaction or usefulness.

Based on the statistical results, perceived ease of use is not a predictor for female learners, but it is a significant positive factor for male learners, on both perceived satisfaction and usefulness. Perceived anxiety is a big issue based on our statistical results. The results show that when female learners have more perceived anxiety toward APP-based m-learning; then they also have more positive perceived satisfaction and usefulness. Unlike male students who have more perceived anxiety toward APPbased m-learning; they have more negative perceived satisfaction and usefulness. The statistical results, for both female and male learners, when they have more perceived satisfaction and usefulness, then they also have more positive behavioral acceptance toward APP-based m-learning.

\section{Conclusions}

In summary, a better understanding of the gender perspectives toward m-learning environments can assist researchers and educators to understand more about how to take into consideration the gender difference when developing m-learning platforms for both female and male learners. Based on the results of Table 1, the results showed that self-efficacy as a better crucial factor for male learners while perceived anxiety was a better critical factor for female students. Unlike previous research of Albert and Johnson (2011) as well as Padilla-Meléndez, et al. (2013), our findings provide evidence that female and male learners have different perceptions toward m-learning environments.

In this research, we proposed an 8-factor conceptual model for investigating the gender differences of attitudes towards an APP-based m-learning system. The factors include perceived self-efficacy, anxiety, self-regulation, ease of use, usefulness, interaction learning, satisfaction, usefulness, and behavioral acceptance. We have designed an APP-based m-learning system that was used by undergraduate students in the context of four different courses. After the period of one month we have collected questionnaires examining students' attitudes and performed the analysis. The results lead to the following conclusions:

First, the proposed model is a suitable conceptual model for understanding female and male learners' attitudes. The proposed research conceptual model is an acceptable conceptual model to survey learners' (including female and male learners) attitudes toward m-learning. In Figure 1, learners' personal factors (such as perceived anxiety, self-efficacy) could predict environmental factors (such 
as interactive learning environments). At the same time, environmental factors also could predict behavioral acceptance factors. Therefore, our research results support previous research of Liaw (2008) and Liaw and Huang (2013).

Second, gender perspective is an issue of learners' attitudes toward m-learning. After investigating our 12 hypotheses as presented in Figure 1, we might conclude that the gender factor could influence learners' attitudes towards m-learning. Perceived anxiety is a positively significant predictor for female learners while perceived self-efficacy and perceived self-regulation have more positive contribution for male learners. Perceived usefulness has the highest contribution on behavioral acceptance toward m-learning for both female and male learners. These results are aligned with previous studies (Carr, 2005; Okazaki \& Renda dos Santos, 2012; Ong \& Lai, 2006) claiming that female and male learners have different cause relationship among attitudes toward m-learning.

Third, Perceived anxiety is a critical factor for female learners. Based on statistical results, perceived anxiety is the most significantly positive predictor on perceived satisfaction and usefulness for female learners. These results can be explained when female learners have higher perceived anxiety toward m-learning; then they also have higher satisfaction. On the other hand, perceived anxiety is a negative predictor on perceived satisfaction and usefulness for male students. These results indicate that when male learners have higher perceived anxiety toward m-learning; then they will decrease their positive feeling toward m-learning.

\section{References}

Albert, L. J. \& Johnson, C. S. (2011): Socioeconomic Status - and Gender-Based Differences in Students' Perceptions of E-Learning Systems. In: Decision Sciences Journal of Innovative Education, 9 (3), pp. 421-436.

Carr, D. (2005): Contexts, gaming pleasures, and gendered preferences. In: Simulation \& Gaming, 36 (4), pp. 464-482.

Chu, R. J. C. (2010): How family support and Internet self-efficacy influence the effects of e-learning among higher aged adults - Analyses of gender and age differences. In: Computers \& Education, 55 , pp. 255-264.

Crompton, H. (2013): A historical overview of mobile learning: Toward learner-centered education. In: Z. L. Berge \& L. Y. Muilenburg (Eds.): Handbook of mobile learning. Florence, KY: Routledge, pp. 3-14.

Liaw, S. S. (2002): An Internet Survey for Perceptions of Computer and World Wide Web: Relationship, Prediction, and Difference. In: Computers in Human Behavior, 18, pp. 17-35.

Liaw, S. S. (2007): Investigating sex differences and learners' autonomy toward e-learning: based on UK and Taiwan surveys. In: Psychological Reports, 100, pp. 949-954.

Liaw, S. S., Hatala, M. \& Huang, H. M. (2010): Investigating acceptance toward mobile learning to assist individual knowledge management: based on activity theory approach. In: Computers \& Education, 54 (2), pp. 446-454.

Liaw, S. S., Huang, H. M. (2013): Perceived satisfaction, perceived usefulness and interactive learning environments as predictors to self-regulation in e-learning environments. In: Computers \& Education, 60 (1), pp. 14-24.

Okazaki, S. \& Renda dos Santos, I. M. (2012): Understanding E-Learning Adoption in Brazil: Major Determinants and Gender Effects. In: International Review of Research in Open and Distance Learning, 13 (4), pp. 91-106. 
Ong, C. S. \& Lai, J. Y. (2006): Gender differences in perceptions and relationships among dominants of e-learning acceptance. In: Computers in Human Behavior, 22, pp. 816-829.

Padilla-Meléndez, A., Aguila-Obra, A. R. \& Garrido-Moreno, A. (2013): Perceived playfulness, gender differences and tech nology acceptance model in a blended learning scenario. In: Computers \& Education, 63, pp. 306-317.

Sun, P. C., Tsai, R. J., Finger, G., Chen, Y. Y. \& Yeh, D. (2008): What drives a successful e-learning? An empirical investigation of the critical factors influencing learner satisfaction. In: Computers \& Education, 50, pp. 1183-1202.

\section{About the Author}

Prof. Dr. Shu-Sheng Liaw: General Education Center, China Medical University, 91 Shiuesh Rd., Taichung 404, Taiwan. Contact: ssliaw@mail.cmu.edu.tw 